\title{
A QUESTÃO DA LIBERDADE EM EMMANUEL MOUNIER
}

\section{THE ISSUE OF FREEDOM IN EMMANUEL MOUNIER}

\author{
João Francisco Cocaro Ribeiro ${ }^{1}$ \\ (joao-cocaro@hotmail.com)
}

\begin{abstract}
RESUMO
O presente artigo tem como objetivo primaz compreender a questão da liberdade na filosofia de Emmanuel Mounier. A questão da liberdade, ao longo da história do pensamento humano, tem recebido diversos desdobramentos, e o tratamento dessa questão a partir do pensamento filosófico de Mounier revela uma grande dificuldade devido a compreensões enviesadas no que diz respeito a esse conceito fundamental da vida humana. Tem-se assim um paradoxo, uma vez que, por um lado, afirma-se a dificuldade de trabalhar essa questão e, por outro, percebe-se no mundo atual uma tendência generalizada de afirmação dela. Trata-se, em última análise, de compreensões distorcidas que, portanto, precisam ser desmistificadas para que desabroche uma autêntica concepção de liberdade humana.
\end{abstract}

Palavras-chave: Liberdade. Mounier. História.

\begin{abstract}
This article aims primarily to understand the issue of freedom in Emmanuel Mounier's philosophy. The question of freedom, throughout the history of human thought, has developed in many ways; and the treatment of such question, from Mounier's philosophical thinking, reveals a great difficulty due to biased understandings regarding this fundamental concept of human life. Thus, there is a paradox, since, on the one hand, the difficulty of working on this issue is affirmed and, on the other hand, there is a widespread tendency in the world today to affirm it. These are distorted understandings which, therefore, need to be demystified in order to unfold an authentic conception of human freedom.
\end{abstract}

Palavras-chave: Freedom. Mounier. History.

\section{INTRODUÇÃO}

\footnotetext{
${ }^{1}$ Graduando em Direito e Teologia pela Universidade Regional Integrada do Alto Uruguai e das Missões (URI).

CV Lattes: http://lattes.cnpq.br/3018100895448854.

ORCID: https://orcid.org/0000-0002-5435-2824.
} 
A raiz da distorção do conceito de liberdade encontra-se, segundo Mounier, na compreensão dualista do universo desenvolvida pela tradição filosófica ocidental, originada na Grécia antiga e reforçada pela filosofia moderna. A partir daí, tem-se compreendido tudo em função de duas dimensões inconciliáveis, que, na verdade, formam uma unidade indissolúvel. Como nossa sociedade atual é marcadamente influenciada por essa visão dualista, há a tendência a se compreender a liberdade humana apenas a partir de uma dimensão.

Sabe-se que a afirmação da liberdade humana é uma das questões fundamentais do pensamento filosófico de Mounier. É necessário, contudo, interrogar: a pessoa, para Mounier, é verdadeiramente livre? Ou a maneira com que Mounier fala da liberdade humana - "é livre e sempre imprevisível” (MOUNIER, 1960, p. 14) - é apenas uma metáfora? É justamente dessa problemática que este estudo pretende participar.

Mounier afirma que a pessoa é sempre e inteiramente livre. A liberdade, contudo, é tanto irredutível a uma coisa material quanto a uma espontaneidade vital - isto é, ela não é uma liberdade dada, cuja real existência pode ser tocada e verificada, nem se reduz à pura subjetividade, tida como manifestação espontânea, sem limitação alguma. A liberdade é, para Mounier, condicionada, resultado da própria condição e situação humanas; é, simultaneamente, o conjunto de condições dadas e poder de ultrapassamento dessas condições.

A liberdade só se dá numa experiência existencial do ser humano; ela é "afirmação da pessoa, vive-se, não se vê" (MOUNIER, 1960, p. 106). Nesse sentido, o ser humano torna-se livre libertando-se dos dados opressivos de sua situação. Na medida em que se considera o ser humano na sua unidade, resulta uma genuína afirmação da liberdade humana: a liberdade, então, "é vida, sentida num esforço de libertação, mais do que facilidades herdadas, uma liberdade dramática" (SEVERINO, 1983, p. 72), e precisa sempre ser reconquistada.

Antes, contudo, de se chegar ao sentido da liberdade humana, há a necessidade de se percorrer um caminho mais longo. Uma vez que a liberdade está assentada na ideia de condição e situação humanas, é preciso que se desenvolva, primeiramente, a noção de pessoa presente no pensamento filosófico mounieriano. Mas, sendo que se defende que compreensões distorcidas da liberdade humana são resultado de uma distorção da noção de pessoa, é imprescindível que se desenvolva a raiz e os diversos desdobramentos dessa distorção.

Assim, desenvolveu-se esse raciocínio a partir de três capítulos. No primeiro capítulo, realizou-se um breve histórico da noção de pessoa e da condição pessoal. Ao se realizar essa análise, destaca-se o quanto a pessoa foi tratada, ao longo da tradição filosófica, de forma unilateral. Dentre as poucas perspectivas de pensamento que valorizaram o ser humano em sua unidade, talvez tenha se destacado o cristianismo; mas este, por 
sua vez, também logo sofreu a influência da visão dualista da pessoa. Essa visão redutora tem acarretado inúmeros problemas para a humanidade; por isso, também foram desenvolvidas as principais consequências que são frutos dessas interpretações unilaterais.

Realizando essas análises, tornou-se possível, num segundo capítulo, apresentar a noção de pessoa presente na filosofia personalista de Mounier, tendo como resultado uma visão que procura contemplar a pessoa em sua unidade. Trata-se de uma noção que toma a pessoa como constituída de espírito e matéria, imanência e transcendência, que não podem ser tomados como dissociáveis. É justamente a dialética do contínuo compromisso entre imanência e transcendência, corpo e espírito, uma das mais fortes expressões do personalismo de Mounier.

Por fim, no terceiro capítulo desenvolve-se o sentido da liberdade humana. Fugindo de duas perspectivas - uma que procura demonstrar a liberdade como determinadas falhas nos determinismos causais, outra que cai no extremo oposto, reduzindo-a a pura subjetividade, como manifestação espontânea, autoinvenção, sem limitação alguma -, Mounier defende que a liberdade é a afirmação da pessoa. Irredutível a uma coisa natural ou a uma espontaneidade vital, a liberdade, na perspectiva personalista de Mounier, é "fonte viva do ser" (MOUNIER, 1960, p. 111).

\section{A CONCEPÇÃO DE PESSOA AO LONGO DA TRADIÇÃO E PROBLEMAS}

Sendo a existência de pessoas livres e criadoras a afirmação central do personalismo, torna-se impossível pretender qualquer sistematização definitiva desse pensamento; mas, apesar de fugir a toda sistematização, o personalismo não pode ser tomado como apenas uma atitude, já que trabalha com conceitos, estruturas e esquemas - portanto, é filosofia que tem como ponto de partida a experiência da pessoa (RUEDELL, 1985, p. 31). Claro, pretender definir a pessoa é se posicionar contra o personalismo, pois, segundo Mounier, definem-se apenas "objetos exteriores, que se encontram ao alcance de nossa vista" (MOUNIER, 1960, p. 15), e não o homem, que é sempre imprevisível.

Ao longo da tradição da humanidade, por diversas vezes se definiu o homem. Chegar à natureza dele era a principal preocupação. Dessas definições, contudo, nunca resultou uma concepção de pessoa que valorizasse todas as suas dimensões; muito pelo contrário, resultaram concepções unilaterais, que, antes de possibilitarem uma melhor compreensão da pessoa, enquadraram-na em conceitos forjados. 
É a esse pensamento redutor que o personalismo de Mounier quer fugir. Preocupado com a pessoa, Mounier denuncia tal concepção redutora e anuncia uma nova perspectiva de pensamento. A pessoa, para ele, nunca poderá ser enquadrada em conceitos. Ela é tudo aquilo que foge à sistematização. Ela não é o mais maravilhoso objeto do mundo, objeto que pode ser conhecido de fora; é, ao contrário, "a única realidade que conhecemos e que, simultaneamente, construímos de dentro. Sempre presente, nunca se oferece" (MOUNIER, 1960, p. 17). Eis o porquê de a pessoa não pode ser tratada como objeto

Eis o meu vizinho. Tem do seu corpo um sentimento único, de que não posso participar; mas posso observar de fora esse corpo, examinar as suas disposições, manifestações hereditárias, formas, doenças, numa palavra tratálo como se tratam matérias do saber fisiológico, médico etc. Se é funcionário terá um regulamento de funcionário, uma psicologia de funcionário, que podem ser estudados no seu caso, embora não se identifique com ele, com ele todo, na sua realidade compreensiva. Do mesmo modo, será ainda um francês, um burguês, um maníaco, um socialista, um católico etc. Mas já não será um Bernardt Chartier; é Bernardt Chartier. As mil maneiras por que eu posso determiná-lo como um exemplar duma classe ajudam-me a compreendê-lo e sobretudo a utilizá-lo, a saber como hei-de comportar quando estou com ele. Não são, no entanto, mais do que facetas fornecidas por cada um dos diferentes aspectos da sua existência. Mil fotografias sobrepostas não nos dão um homem que anda, que pensa, que quer. (MOUNIER, 1960, p. 16)

Esse tipo de pensamento redutor é, sem sombra de dúvida, a antítese do universo pessoal. Trata-se de um grande pecado contra a pessoa. Na medida em que esses conceitos se entregam a capas de tranquilidade, em que nada se cria, em que não há riscos, nega-se a pessoa. Abdica-se, assim, do universo pessoal, da condição de existentes "fervorosos, livres e responsáveis, que enfrentam o destino em lucidez e coragem" (MOUNIER, 1963, p. 17), "faz[se] da humanidade uma imensa e perfeita casa de bonecas" (MOUNIER, 1960, p. 17).

Apesar desses pensamentos, que enquadram a pessoa em determinados conceitos, os recursos da pessoa são indefinidos: "nada do que a exprime a esgota, nada do que a condiciona a escraviza" (MOUNIER, 1960, p. 17). Por isso, é sempre possível pensar novas possibilidades. Antes, contudo, de fornecer novas perspectivas, Mounier apresenta uma breve história da noção de pessoa e da condição pessoal. Há a necessidade de se ter uma ideia sumária do que foi a tradição do pensamento da humanidade, a fim de se visualizarem e denunciarem as perspectivas redutoras, mas também de se absorverem perspectivas que valorizam o universo pessoal.

\subsection{A concepção de pessoa ao longo da tradição}


Ao se analisar o pensamento humano, percebe-se o quanto a pessoa foi tratada de forma unilateral; e, ainda, na medida em que surgia uma perspectiva com conotação diversa, esta era completamente negada ou, se de outra forma não fosse possível, era envolvida com o manto redutor da tradição. Para se compreenderem melhor os traços apresentados, faz-se necessário acompanhar o desenvolvimento do pensamento humano desde o início da filosofia até os dias mais atuais.

No pensamento antigo, a pessoa está completamente imersa na família e na pólis. Os seres humanos encontram-se submetidos por um destino cego a tal ponto que a escravatura não choca os filósofos da época; ao contrário, a escravatura é ratificada por eles, afirmando-se que é da natureza de alguns serem servos e de outros, senhores. Diante disso, qual é a preocupação dos filósofos da época? "Os filósofos apenas se preocupam com o pensamento impessoal e sua ordem imóvel que rege simultaneamente a natureza e as ideias.” (MOUNIER, 1960, p. 20)

O singular, nessa concepção, é tomado no máximo como sombra das ideias - a tal ponto que Platão procurou reduzir o singular a uma participação na Natureza. Platão divide a realidade em mundo material (imperfeito) e mundo das ideias (perfeito e universal), afirmando que a alma está presa ao corpo por ter decaído por um processo de corrupção. Aristóteles, mesmo que afirme que somente o singular é real, afirma também que seu motor imóvel jamais pode ter uma vontade particular, nem conhecer essências singulares (MOUNIER, 1960, p. 20)

Tanto um como outro submetem o homem pessoal e ativo a um ser fictício impessoal. Na realidade, a natureza nada mais nos dá, nada mais entrega ao nosso conhecimento racional do que um feixe infinitamente complicado de indeterminações, das quais nem chegamos a saber se, para além dos sistemas que formulamos para assegurar nossa marcha, serão redutíveis a uma unidade lógica. (MOUNIER, 1960, p. 39)

É nos escritos dos primeiros filósofos que se encontra a separação de duas realidades: corpo e espírito, natureza e transcendência. O cristianismo procura romper com essa visão. A visão no texto Bíblico não é assim, excetuando-se o livro da Sabedoria, que tem influência da concepção grega por ter sido escrito em Alexandria. O conjunto das concepções expressas nas Sagradas Escrituras não manifestam, segundo Mounier, esse tipo de dualismo, e sim uma tendência unitária que não permite a separação de planos distintos, como corpo e alma, religião e realidade social, entre outras - ao contrário dos gregos, para quem corpo e alma ou matéria e espírito eram realidades totalmente distintas e opostas.

O Ser Supremo das Sagradas Escrituras não confere unidade aos seres humanos a partir de uma abstração da ideia; cada ser humano é único, capaz de 
multiplicar indefinidamente atos de amor únicos (MOUNIER, 1960, p. 22). O ser humano não é tomado como uma imperfeição, mas como uma multiplicidade que se vai constituindo na infinita força de amor para com os demais seres humanos: "O indivíduo deixa de ser o cruzamento de várias participações em mais gerais realidades (matéria, espírito, ideias etc.) para ser um todo indissociável, cuja unidade, porque no absoluto assente, prece a multiplicidade" (MOUNIER, 1960, p. 22).

Trata-se, no fundo, de um chamado à existência. Ela jamais pode ser assimilada a uma ideia abstrata da natureza ou das ideias metafísicas; é, ao contrário, segredo dos corações de todos os existentes, os quais podem decidir-se livremente, pois Deus não tem feito o ser humano perfeito: "preferiu que ele fosse chamado a amadurecer livremente a humanidade e os efeitos da vida divina" (MOUNIER, 1960, p. 23). O ser humano tem o direito de pecar, errar, sendo tal direito essencial para seu pleno uso da liberdade. Se não fosse assim, o ser humano jamais deixaria de participar de uma tirania de uma ideia abstrata de Destino. Na concepção de base do cristianismo, segundo Mounier,

[...] já não reina a tirania abstrata de um Destino, duma constelação de ideias ou de um Pensamento Impessoal, indiferentes a destinos individuais, mas um Deus que é ele próprio pessoal, embora dum modo eminente, um Deus que "entregou a sua pessoa" para assumir e transfigurar a condição humana, e que propõe a cada pessoa uma relação única em intimidade, uma participação na sua divindade; um Deus que se não afirma, como pensou o ateísmo moderno (Bakounine, Feuerbach), sobre coisas arrancadas ao homem, mas que antes lhe outorga uma liberdade análoga à sua, pagando-lhe em generosidade o que em generosidade for dado. (MOUNIER, 1960, p. 22)

Pela primeira vez é pensada a eminente relação do gênero humano. Não há separação de dois mundos. O Deus da base do cristianismo não se encontra completamente isolado do ser humano; a pessoa é criada à imagem de Deus e chamada a formar um imenso corpo místico na caridade de Cristo (MOUNIER, 1960, p. 24). A própria concepção de Trindade, o Pai, o Filho e o Espírito Santo, é manifestação dessa unidade. Esse Deus jamais poderá ser tomado como Ser Supremo isolado da humanidade, que se diverte com os erros realizados por eles, num plano onde tudo já está determinado. Tem-se, portanto, na base do cristianismo, uma genuína afirmação da liberdade humana.

Essa visão, porém, era demasiado nova para a época; em nossos dias, é difícil imaginar o escândalo que deve ter provocado para os gregos. Prova disso é que essa concepção de base do cristianismo logo sofreu a influência do pensamento grego. Embora o cristianismo tenha lutado, desde seu surgimento, contra a tentação dualista, não 
permaneceu por muito tempo imune a essa visão arrasadora. Segundo Mounier, na Idade Média o cristianismo foi platonizado, apesar das tentativas de afirmação da dignidade da matéria e da unidade da constituição humana (MOUNIER, 1960, p. 25).

Com Descartes acontece uma nítida mudança. O voluntarismo havia preparado o caminho por onde poderia percorrer o pensamento filosófico cartesiano. Muitas interpretações, porém, dissolvem a filosofia cartesiana no racionalismo e no idealismo moderno, que, por sua vez, dissolvem a existência concreta na ideia, esquecendo a riqueza do cogito. Trata-se, antes de ser uma dissolução na ideia, de uma conversão à existência: "Daí para diante a filosofia deixa de ser uma lição que se aprende, como era costume na escolástica decadente, para ser uma meditação pessoal, e a cada um é pedido que, por sua conta, a refaça” (MOUNIER, 1960, p. 25).

O pensamento cartesiano, contudo, não é apenas afirmação da existência; traz consigo "germes do idealismo e solipsismo metafísicos que minarão profundamente o personalismo clássico de Leibniz aos kantianos" (MOUNIER, 1960, p. 25). Decorre daí o idealismo hegeliano: "Hegel fica-nos sobretudo como o arquiteto imponente e monstruoso do imperialismo da ideia impessoal. Todas as coisas, todos os seres, vão-se dissolvendo na sua representação; não foi por acaso que ele veio a defender a total submissão do indivíduo ao Estado" (MOUNIER, 1960, p. 26). Analisando o pensamento hegeliano, Mounier se pergunta pelo lugar da pessoa nesse sistema. Não há lugar para a pessoa. Isso se expressa claramente na expressão hegeliana: "tudo o que é real é racional, tudo o que é racional é real" (MOUNIER, 1963, p. 22). Hegel construiu, na verdade, uma catedral que baniu o mistério do mundo e do homem.

Em torno do monumento idealista hegeliano, sobressaem posicionamentos que se esforçam em afirmar a dialética da pessoa face ao idealismo solapador. Segundo Mounier, diversos pensadores deram significativas contribuições ao personalismo, a saber, Leibniz, Kant, Pascal, Kierkegaard, Rousseau, Malebranche, Goethe e Maine de Biran. Kierkegaard, por exemplo, é considerado por Mounier como o "profeta da grandeza paradoxal e dramática do homem, levanta-se contra o otimismo do conforto burguês e da razão fácil" (MOUNIER, 1960, p. 28).

Opondo-se ao sistema hegeliano, Kierkegaard defende a impossibilidade de se construírem sistemas da existência. A existência jamais pode ser reduzida a sistema. "Paralelamente a Kierkegaard, Marx acusou Hegel de fazer do espírito abstrato, e não do homem concreto, o sujeito da história, reduzindo à ideia a realidade viva dos homens" (MOUNIER, 1960, p. 28). Marx posiciona-se contra toda forma de 
despersonalização humana; para ele, segundo Mounier, a dissolução do homem na ideia encontra-se nitidamente expressa "no mundo capitalista que trata o homem trabalhador como objeto da história e que, ao mesmo tempo em que o expulsa de si próprio, o expulsa de seu reino natural" (MOUNIER, 1960, p. 28). Trata-se de um convite realizado para a filosofia, a fim de que trate dos problemas essenciais da vida moderna, libertando-se das mistificações idealistas.

Tem-se, a partir de Marx, uma série de pensadores preocupados em renovar problemas personalistas; esses todos não serão evocados aqui. A preocupação é mais perceber quais correntes ou movimentos filosóficos dissolveram a pessoa num emaranhado de conceitos metafísicos redutores do que trazer ao presente todo o desenvolvimento do pensamento filosófico. Além do mais, o cristianismo, Kierkegaard e Marx, que se destacam por colocarem a pessoa em primeiro plano, foram tratados de maneira bastante pontuada. Resta, contudo, compreender os principais problemas e consequências acarretadas por esse pensamento redutor.

\subsection{Problemas acarretados pela visão redutora}

A Revolução Francesa sem dúvida é um momento que marca um lento desenvolvimento da condição humana; é um momento especial, pois possibilita a libertação política e social. Apesar de todos os esforços, esse tempo traz seus problemas. Há, nesse momento, a derrocada da estrutura feudal realizada pela burguesia, e esta, posicionando-se contra uma estrutura demasiado pesada, fecha-se num individualismo, ratificando a ideia de que todo revolucionário traz em seu bojo o desejo reacionário.

Essa libertação encontra-se limitada pelo individualismo burguês. O ser humano encontra-se completamente perdido na nova ordem social, realizando uma busca desenfreada por um lugar na nova sociedade: "Recuando perante essas novas angústias, e temendo as imprudências do desejo, o mundo do pequeno burguês recalca-o por detrás de uma aparência de medíocres satisfações: instaura o reino do individualismo cauteloso" (MOUNIER, 1960, p. 30).

O homem europeu vive uma crise, fruto do mundo burguês. Convencida da possibilidade de dominar o mundo e domesticar as paixões a partir, respectivamente, da técnica e do racionalismo, a humanidade moderna entrega-se à triste ideia da razão unificadora. Decorre daí, porém, uma terrível frustração; hoje, "a crise espiritual é a crise do homem clássico europeu, nascido com o mundo burguês" (MOUNIER, 1960, p. 165). Três pensadores da humanidade revelam claramente o desequilíbrio moderno 
Em cem anos foram dadas três machadadas nesta civilização demasiado convencida do seu equilíbrio: para lá das harmonias econômicas, Marx revelava a luta sem tréguas de profundas forças sociais; para lá das harmonias psicológicas, Freud descobria o turbilhão dos instintos; finalmente, Nietzsche anunciava o niilismo europeu antes de passar o facho a Dostoievsky. As duas guerras mundiais, o aparecimento dos estados policiais e do universo concentracionário orquestraram depois largamente estes temas. (MOUNIER, 1960, p. 166)

A civilização moderna sofre de uma crise espiritual, uma verdadeira crise de valores e da própria civilização. A sociedade burguesa foi organizada a partir do econômico; houve, assim, uma inversão de todas as leis da economia. O homem foi colocado a serviço do capital e do lucro, em vez de com eles satisfazer as necessidades humanas. Há uma completa indiferença da economia para com as pessoas que ela põe em jogo: "Como tal não conhece medidas, nem regras, a não ser as que ela mesma se atribui: os valores da burguesia" (RUEDELL, 1985, p. 50). Eis, no dizer de Mounier, a crise que vive o homem moderno

[...] a crise de estruturas mistura-se com a crise espiritual. Através duma economia sem sentido, a ciência segue o seu curso impassível, redistribui as riquezas e perturba as forças. As classes sociais desagregam-se, as classes dirigentes caem na incompetência e na indecisão. O Estado procura-se no tumulto. Finalmente, a guerra ou a preparação para a guerra, resultante de tantos conflitos, paralisa de há trinta anos para cá o melhoramento das condições de existência e das funções primárias da vida coletiva. (MOUNIER, 1960, p. 167)

Como se vê, a divisão do homem em duas substâncias independentes tem acarretado enormes dificuldades. Quando não dissolvido em conceitos abstratos, a saber, ideia, Espírito, o ser humano é tratado de forma unilateral, de modo que se valorize apenas uma de suas dimensões: "a junção dos dois mundos é então inexplicável” (MOUNIER, 1960, p. 35). Na maioria das vezes, nega-se completamente o mundo material, corporal, natural, considerado simplesmente aparência do espírito e não tendo, portanto, validade alguma. É com esse pernicioso dualismo que o personalismo quer acabar, tanto na maneira de viver quanto de pensar. Pois

O século XVIII pensou que a única solução para escapar às paixões das sociedades irracionais estava numa sociedade racional, fundada no acordo dos espíritos num pensamento impessoal, e no acordo dos comportamentos numa ordem jurídica formal. Pensavam que assim caminhariam para a paz universal através da instrução obrigatória, da organização industrial ou do reinado do direito. A experiência iria demonstrar que o saber não agita paixões, que o direito formal pode sufocar desordens persistentes, que a organização e a 
ideologia, quando desprezam o absoluto pessoal, levam, tal como as paixões, à polícia, à crueldade e à guerra. Numa palavra, que não se pode estabelecer a universalidade esquecendo a pessoa. (MOUNIER, 1960, p. 71, grifos do autor)

Mounier não se conforma com a mentalidade do mundo moderno. Essa sociedade se encontra sustentada em falsos valores. Não há, na verdade, valorização do mistério, da criatividade, da individualidade, da impenetrabilidade da pessoa; há apenas um indivíduo abstrato e solitário, desencarnado do mundo em que vive. Por isso, há necessidade de se salvar o homem.

Uma vez demonstradas as interpretações unilaterais da pessoa, pode-se acabar com o divórcio realizado entre espírito e matéria, pensamento e ação etc. (MOUNIER, 1960, p. 23) e se compreender "a pessoa no paradoxo ou na tensão entre a transcendência e a imanência; o individual e o social (ou coletivo); a subjetividade e a objetividade; a conversão íntima e o afrontamento, enfim, entre personalização e a despersonalização” (RUEDELL, 1985, p. 31).

\section{UMA NOVA NOÇÃO DE PESSOA}

Tendo chegado até aqui, poder-se-ia esperar que o personalismo começasse a definir a pessoa, mas esse ser, o homem, não é objeto de definição; ele é, antes, apenas atingível através de uma experiência vivencial, e não teorética. Se é possível circunscrever e assinalar essa experiência progressiva de uma vida, é porque ela não se limita a uma visão parcial daquilo a que se visava atingir por inteiro. O ser humano não se entrega a um instrumento como os demais objetos. Ciência ou filosofia que assim o faz, segundo Mounier, esvazia a presença real da pessoa.

É preciso considerar que o "espírito conhecente é um espírito existente" (MOUNIER, 1963, p. 23), não em virtude de uma lógica imanente, mas de uma decisão pessoal e criadora. Nesse sentido, todo sistema se interpõe entre o filósofo existente e os demais existentes. Uma simples definição teorética jamais poderia exprimir a complexidade da pessoa, "razão profunda que impede que a existência possa ser reduzida a sistema. O sistema pertence à classe do repertório ou do instrumento. Coleciona e articula. Mas o inesgotável não se conta e o inalcançável não se articula” (MOUNIER, 1963, p. 32).

É por isso que Mounier questiona: “conhecer será realmente a primeira palavra? Para nos conhecermos e conhecermos o mundo com um conhecimento 
pleno e fervoroso, não deverá o próprio homem ser uma existência plena e fervorosa?" (MOUNIER, 1963, p. 20). Por diversas vezes o racionalismo pensou ter perscrutado toda a complexidade do ser humano, mas entregou-se a um sono vital ao invés de assumir de forma fervorosa a existência. A primeira atitude da filosofia, portanto, não pode ser uma tentativa de conhecimento, pelo menos no sentido tomado pelo racionalismo; consiste, antes, em fazer a vida renascer. É um apelo: "Homem, acorda" (MOUNIER, 1963, p. 27) desse seu sono vital. Pois

A pessoa não é como uma forma, um existente não é molde no qual se imprimam ideias, convicções ou instruções, é movimento dialético dum pensamento explícito para um pensamento refletido, de uma vontade surda e obscuramente agente para uma vontade agida, e a ideia, o apelo, a ordem, mesmo que sejam transcendentes, devem ir buscar no seio desse movimento as disposições que vão preencher. É preciso que o pensamento se faça carne, carne de existência, e cada homem, carne da sua existência. (MOUNIER, 1963, p. 23)

Historicamente esqueceu-se que o ser humano é um existente que "não pergunta em vão. Não procura $a$ verdade, uma verdade impessoal e diferente para todos, mas, numa promessa de universalidade, indubitavelmente viva, a sua verdade, uma verdade que corresponda às suas aspirações, preencha as suas expectativas, resolva os seus problemas" (MOUNIER, 1963, p. 23). O racionalismo e a atitude positivista negam a existência, pois transformam o ser humano "num feixe de ideias e conceitos dissolventes, num mundo de pontos infinitos e indiferentes. $\mathrm{O}$ mistério do ser, a plenitude e a densidade da existência não têm mais seu lugar neste universo pretensamente exaustivo de explicitação" (SEVERINO, 1983, p. 38).

Diante de todas essas colocações, poder-se-ia perguntar pela possibilidade de ainda se elaborar uma noção de pessoa, pois "o nosso tempo repugna a ideia duma natureza humana permanente, exatamente porque tomou consciência das possibilidades ainda inexploradas da condição humana" (MOUNIER, 1960, p. 73). Apesar de crítico quanto à possibilidade de realizar exaustivamente uma noção de natureza humana, Mounier crê na possibilidade de elaborar uma noção de pessoa. A ideia de noção humana elimina o perigo de se considerar o ser humano como um simples existente vazio sem um futuro e sem finalidades. Tem-se, assim, uma dupla negação: negação da ideia de que a pessoa é um objeto circunscrito que facilmente se apreende e negação da ideia que toma o homem como um ser que simplesmente se faz.

Mounier visa, ao falar de noção humana ou condição humana, o modo propriamente humano de existência. Seu "ponto de partida da filosofia é a experiência existencial da pessoa" (RUEDELL, 1985, p. 31). Severino, defendendo 
que Mounier foge de dois modos de tratar a pessoa, cita uma passagem de Mounier, especificamente de sua obra Qu'est-ce que le personnalisme?: "Mounier se eleva contra 'a representação do tipo aristotélico que expõe (étale) e imobiliza esta unidade num conteúdo desde a origem cheio de todos os seus traços futuros'; contra tal representação não oporá, contudo, 'uma espécie de espontaneidade insensata e, por isto, entregue cegamente às servidões do universo"” (SEVERINO, 1983, p. 33).

Mesmo rejeitando definições formais, Mounier não exclui de seu pensamento a noção de condição humana. A pessoa, portanto, não foi relegada ao indizível: "Uma coisa é rejeitar a tirania das definições formais, outra é recusar ao homem, como por vezes o faz o existencialismo, toda essência e toda estrutura. Se cada homem não é senão aquilo que se faz, então não há nem humanidade, nem história" (MOUNIER, 1960, p. 73).

Sem ser capaz de abraçá-la em sua significação, em seu caminhar livre, Mounier concebe a noção de pessoa como uma permanência aberta à determinação. Ao tratar de estruturas do universo pessoal, Mounier não quer precisar essências, mas tratar da própria abertura de um absoluto permanente. Nesse sentido, a pessoa, apreendida numa experiência global, revelar-se-á uma atividade, “em oposição às coisas, pelo pulsar duma vida secreta onde incessantemente parece destilar a sua riqueza" (MOUNIER, 1960, p. 75).

\subsection{A indissolúvel união da alma e do corpo}

As tentativas filosóficas da história na sua maioria das vezes consideraram o ser humano como composto de dois elementos independentes e justapostos: um material e outro espiritual. Diante disso, a significação filosófica do personalismo de Mounier está exatamente na concepção unitária da pessoa como corpo e espírito. É preciso, segundo Mounier, superar essa dissociação perniciosa e pensar o ser humano de forma integral se se quiser realmente entender o que é a pessoa humana - superar, portanto, tais "resíduos cátaros da filosofia" é fundamental para se pensar a pessoa em sua totalidade.

Na perspectiva personalista de Mounier, o ser humano é “integralmente 'corpo' e é integralmente "espírito"' (MOUNIER, 1960, p. 36). O ser humano se encontra profundamente enraizado na natureza, e há uma série de elementos que o condicionam: determinações psicológicas, natureza material, participações sociais não personalizadas (MOUNIER, 1960, p. 38). Trata-se de um conjunto de condicionamentos que não podem ser tomados como simples circunstâncias acidentais, mas como componentes fundamentais da realidade humana 
O meu feitio e a minha maneira de pensar são amoldados pelo clima, a geografia, a minha situação à face do globo, a minha hereditariedade, e talvez, até, pela ação maciça dos raios cósmicos. Para além destas determinações influenciais, temos ainda posteriores determinações psicológicas e coletivas. Nada há em mim que não esteja imbuído de terra e sangue. (MOUNIER, 1960, p. 36)

Segundo Mounier, o pensamento cristão sempre considerou essa unidade: "nunca opôs 'espírito', 'corpo' ou 'matéria', na acepção moderna deste termo" (MOUNIER, 1960, p. 36). Para a base do cristianismo, o próprio espiritual é carnal; por isso, "o cristão que fala com desprezo do corpo e da matéria fá-lo contra sua mais central tradição" (MOUNIER, 1960, p. 37). O corpo, a matéria, contudo, na acepção dos gregos, ao contrário do que se percebe na base do cristianismo, foi considerado com desprezo. Desconsiderou-se que o ser humano é um ser corporal. É através do corpo que o ser humano se enraíza, faz parte concretamente da natureza. O ser humano é integralmente corpo e espírito; daí a importância de se considerar o inconsciente psicológico, a natureza exterior como constituinte da existência humana. Nessa perspectiva não há mais lugar para dualismo. É pela corporeidade que o ser humano se insere na dinâmica da natureza, seguindo os impulsos da corrente da vida. Quer dizer, o desenvolvimento espiritual do ser humano se encontra profundamente ligado com o corpo, a matéria: "estudos vários demonstram que as grandes religiões seguem os mesmos caminhos que as grandes epidemias" (MOUNIER, 1960, p. 36). Trata-se, portanto, de um pensamento que toma a pessoa como expressão bivalente de uma unidade fundamental

\begin{abstract}
Não posso pensar sem ser, nem ser sem o meu corpo: através dele, exponhome a mim próprio, ao mundo, aos outros, através dele escapo à solidão dum pensamento que mais não seria do que pensamento do meu pensamento. Recusando-se a entregar-me a mim próprio, inteiramente transparente, lançame sem cessar para fora de mim, na problemática do mundo e nas lutas do homem. Através das solicitações dos sentidos lança-me no espaço, através do seu envelhecimento ensina-me o tempo, através da sua morte lança-me na eternidade. A sua servidão pesa-me, mas ao mesmo tempo é base para qualquer consciência e para toda a vida espiritual. É mediador omnipresente da vida do espírito. (MOUNIER, 1960, p. 47)
\end{abstract}

Mounier quer, na verdade, desfazer a ideia de acordo com a qual tudo o que se aproxima da alma e do espírito é divino e tudo o que se aproxima do corpo é superficial e, por que não dizer, maligno. Segundo ele, "já nos Evangelhos a malícia e as perversões do Espírito provocaram mais maldições do que as da 'carne', no sentido restrito da palavra" (MOUNIER, 1960, p. 37). É através do corpo que o ser humano se acha 
em profunda sintonia com a natureza; é através dele que se manifesta, que se mostra o espírito humano. Enfim, "efetivamente, existir subjetivamente, existir corporalmente são uma única e mesma experiência" (MOUNIER, 1960, p. 47).

\subsection{A pessoa: imergente/emergente na/sobre a natureza}

A existência pessoal encontra-se profundamente enraizada na natureza, mas também é mais do que simples determinismos. Não há, com certeza, como negar que a pessoa está mergulhada na natureza; entretanto, é capaz de transcendê-la. A pessoa imersa na natureza, emergindo dela, transcende. É essa dialética do contínuo compromisso entre a natureza e a transcendência humana uma das mais fortes expressões do personalismo de Mounier.

Há toda uma série de determinismos que asseguram e limitam o ser humano. A natureza, devidamente encarada, como dizia Mounier, resume-se "num feixe infinitamente complicado de determinações" (MOUNIER, 1960, p. 39); contudo, qualquer tentativa de redução da pessoa a artifícios lógicos de relações não expressa mais do que um belo artifício de laboratório, porque a pessoa, além de ser natural, é um ser humano. O ser humano não é apenas natural, não é um simples joguete da natureza; é capaz de transcender a natureza e, por isso, somente pode ser captado a partir de um exercício vivo de sua atividade global.

A dificuldade, porém, é fazer esse exercício de transcendência. O espírito humano tem certa tendência de resistência "à representação duma realidade que esteja inteiramente inserida numa outra, na sua existência concreta, e que, no entanto, lhe seja superior em nível de existência" (MOUNIER, 1960, p. 38). O ser humano é uma permanente tendência ao nivelamento. Para além dessa tendência negativa, no entanto, o ser humano tem uma capacidade distintiva que o impulsiona à transcendência: ele é capaz de romper com os determinismos, com a inércia de movimentos, com os automatismos, porque é capaz de conhecer esse universo que o absorve e, por isso, pode transformá-lo. Além do mais, possui capacidade de amar, de liberdade.

Não há como negar a natureza. Esse é fator essencial da situação pessoal. A pessoa, contudo, não se mantém imersa, não se contenta com sofrer a ação da natureza, mas é capaz de voltar a ela e impor a capacidade de seu universo pessoal. É nesse sentido que Mounier afirma que as descobertas dos numerosos e estreitos determinismos que encerram o ser humano são sempre fator de libertação para o homem, que, buscando, transcender a natureza, pode servir-se de seus determinismos 
O homem não é encerrado no seu destino pelo determinismo. Se nos mantemos concretamente ligados a numerosos e estreitos determinismos, cada novo determinismo que os sábios descobrem é mais uma nota na gama de nossa liberdade. Enquanto se desconheceram as leis da aerodinâmica, os homens sonhavam voar; quando o seu sonho se inseriu num feixe de necessidades, voaram. Sete notas são pequeno registo: no entanto, foi com estas sete notas que vários séculos de invenção musical se estabeleceram. Aquele que invoca fatalidades naturais para negar as possibilidades do homem abandona-se a um mito ou tenta justificar uma demissão. (MOUNIER, 1960, p. 41)

Mounier destaca que "desde as formas mais elementares de minha existência me afirmo como pessoa e, nunca sendo fator de despersonalização, muito pelo contrário, a minha existência incarnada é fator essencial de minha situação pessoal” (MOUNIER, 1960, p. 47). Contudo, apesar de ter presente que facilmente o ser humano pode alçar voos que permitem a personalização, sabe que muitas vezes os homens têm se jogado na multiplicidade das determinações naturais, deixando-se levar pelo automatismo, hábito, rotina, ideia geral etc. Por isso, uma das principais atitudes do personalismo é de consciência pessoal diante do meio natural. A primeira atitude de grandeza está na aceitação do real. Sem se adaptar aos condicionamentos dos determinismos em que se descobre, a pessoa pode transcendê-los, fazer deles pedestal para a personalização: "Numa primeira fase, a consciência pessoal afirma-se assumindo o meio natural. A aceitação do real é a primeira tentativa de toda a vida criadora. Aquele que a recusa delira, e a sua ação perde-se" (MOUNIER, 1960, p. 49). Porém, esse é apenas o primeiro passo; não se pode parar na aceitação dos determinismos da realidade humana, porque a exploração da natureza tem como fim articular sobre ela, perante a liberdade, possibilidades de humanização, e não apenas a compreensão dos feixes de determinismos

É a força da afirmação pessoal que destrói os obstáculos e rasga novos caminhos. É por isso que devemos negar a natureza como dado, para a afirmar como obra, como obra pessoal, suporte de toda a personalização. Então a dependência da natureza torna-se domínio da natureza, o mundo insere-se na carne do homem e no seu destino. (MOUNIER, 1960, p. 49)

Da forma como foi exposta acima, contudo, poderia parecer uma entrega do ser humano a uma desenfreada submissão da natureza a seu domínio; por isso, é preciso dar um sentido a essa ação sobre a natureza, caso contrário, corre-se o risco de impulsionar o desenvolvimento de catástrofes. Não se trata de um delírio de afirmação pessoal, delírio manifesto por Ford quando o perguntaram o porquê do desenvolvimento incessante de suas empresas, ao que respondeu: "Porque não posso parar", mas de uma libertação da humanidade 
a partir da natureza. Ela não pode ser tomada como uma relação de senhor e escravo, pois "a pessoa só se liberta libertando. E é chamada tanto para libertação da humanidade, como das coisas" (MOUNIER, 1960, p. 49).

Não se mantém, dessa forma, uma relação de exterioridade para com a natureza. O ser humano se apoia nela para vencê-la. Humanizando-a o ser humano também se humaniza. Sob essa concepção, o desenvolvimento técnico e a produção adquirem um sentido profundo. A técnica e a produção precisam possibilitar o instaurar de um mundo de pessoas, não se entregando a interesses parasitas ou à sua própria embriaguez. Elas se tornarão libertadoras na medida em que forem modeladas às exigências do ser pessoal

\begin{abstract}
Neste sentido, produzir é uma atividade essencial da pessoa, desde que demos à produção essa total perspectiva que faz com que ela arraste as mais humildes tarefas no sopro divino que impele a humanidade. [...] É verdade, o poder de abstração da máquina é assustador: rompendo os contatos humanos, pode fazer esquecer, mais do que nenhuma outra força, os homens que compromete, que por vezes esmaga; perfeitamente objetiva, inteiramente explicável, faz perder o hábito da intimidade, do segredo, do inexprimível; dá aos imbecis meios inesperados; e, acima disto, diverte-nos fazendo-nos esquecer as suas crueldades. Entregue ao seu peso cego, é uma poderosa força de despersonalização. Mas não o é senão desligada do movimento que a suscita, como instrumento de libertação do homem das servidões naturais e de reconquista da natureza. (MOUNIER, 1960, p. 51-52)
\end{abstract}

Não obstante todas as investidas do universo pessoal ante a natureza, ele também se apresenta em constante ameaça de despersonalização. Todo movimento de personalização traz em si inúmeras dificuldades, pois "a matéria é rebelde e não somente passiva; ofensiva e não somente inerte" (MOUNIER, 1960, p. 53). Nada da relação pessoal com a natureza permite uma harmonia: "Em toda a parte onde a pessoa leva a sua luz, a natureza, corpo e matéria, insinua a sua opacidade: debaixo das fórmulas do sábio, debaixo da claridade da razão, debaixo da transparência do amor" (MOUNIER, 1960, p. 53). O ser humano não pode se entregar à ideia de que um dia submeterá totalmente o mundo, pois se encontra num "otimismo trágico onde encontra a sua justa medida num clima de grandeza e de luta" (MOUNIER, 1960, p. 54).

A pessoa, portanto, não é apenas dado; ela é também projeto, capaz de superar os condicionamentos que a natureza lhe impõe. Não se trata de pura passividade, mas de um chamado à existência. Cada ser humano precisa se humanizar. É um chamado à responsabilidade: "O inseto que se confunde com um ramo, para se fazer esquecer na imobilidade vegetal, prefigura o homem que se enterra no conformismo para não assumir as responsabilidades próprias, o que se entrega às ideias gerais ou às efusões 
sentimentais para não ter que afrontar fatos e homens" (MOUNIER, 1960, p. 19). A pessoa é capaz de se libertar, de se apossar de si e de se tornar disponível aos outros. Mas somente assim o faz aquele que não se entrega à morbidade vegetal.

Para Mounier, o ser humano, em oposição às coisas, manifesta o pulsar incessante de sua riqueza. Ele pode, sem dúvida, viver conforme uma pedra, pode viver, como destacaram vários filósofos, no divertimento, no estado estético, na vida inautêntica, na alienação, na máfé (MOUNIER, 1960, p. 78). Mas pode transcender, e é chamado a transcender. Voltando-se à natureza, o ser humano é capaz de se lançar aos mais recônditos recantos do universo.

Essa rica dimensão de ultrapassamento do ser humano a partir da natureza é bem destacada por Mounier através da metáfora do avião e da bicicleta: "tal como a bicicleta ou o avião só se equilibram quando se movem para lá duma dada força, o homem só se mantém de pé com um mínimo de força ascensional” (MOUNIER, 1960, p. 124). Sendo assim, a busca de transcendência da pessoa não se dá numa simples agitação, mas na negação do ser isolado em seu brotar: "A vida pessoal começa com a capacidade de romper contatos com o meio, de ripostar, de recuperar" (MOUNIER, 1960, p. 78).

Uma das manifestações de que o ser humano não é simples joguete nas mãos da natureza é sua singularidade, individualidade. A pessoa não é simples "coisa" que pode ser captada ao final de suas análises; a pessoa é "inconfundível com os objetos ou com os seres da natureza, cada pessoa é um universo pessoal" (LORENZON, 1996, p. 70). Ela traz seu segredo, é capaz, através de um só golpe, de romper com os aguilhões que a prendem, sem, porém, libertar-se por completo. Mounier, portanto, destaca a impossibilidade de se chegar aos santuários da pessoa sem atravessar a vida vegetativa. Por isso, é também preciso estar sempre vigilante para que o peso vegetativo não abafe a capacidade de romper, de ir além, enfim, de transcender a realidade dada.

Muitas vezes buscou-se um ideal de existência em que nada mais pesaria; tal ideia se apresenta completamente contra uma genuína afirmação da existência. Aquele que nega os condicionamentos a que o ser humano se encontra submetido nega também a vida. Transcender é lutar contra o sono vital, contra a inércia material; acontece, porém, que "a maioria dos homens prefere a escravidão na segurança ao risco na independência, a vida material e vegetativa à aventura pessoal” (MOUNIER, 1960, p. 103). Isso também revela a facilidade de se deixar levar pela vida vegetativa

O homem é um perene compromisso, uma constante melodia tocada simultaneamente em dois teclados. Por isso, quando se 
encara a melodia tal qual soa como se viesse de um único teclado, foge-se, deixa-se escapar sua realidade. Percorridos os diversos pontos em que se mostra a condição do homem, pode-se dizer que ele é um ser encarnado, situado, imerso na natureza, mas é forçoso reconhecer que em cada um destes pontos onde se vê realçada esta imersão, tem-se o reverso da medalha, tem-se a nota da transcendência do homem. (SEVERINO, 1983, p. 58)

É nessa noção de pessoa que se situa a liberdade humana, entendida enquanto transcendência da natureza dada.

\section{A CONDIÇÃO HUMANA E A LIBERDADE}

O sentido da liberdade, em Mounier, está profundamente enraizado em uma noção de pessoa. Todo o desenvolvimento anterior foi necessário para a compreensão do sentido que Mounier dá para a liberdade. A liberdade, para Mounier, não é algo de volátil, mas se dá na emergência da pessoa sobre a natureza; trata-se, no fundo, de uma liberdade com condições, sendo a mais alta expressão da transcendência humana.

A liberdade, na verdade, já recebeu muitas conotações. Os liberais se proclamam seus maiores defensores; os marxistas os combatem defendendo o "verdadeiro 'reino da liberdade' para lá das caricaturas" (MOUNIER, 1960, p. 105); existencialistas e cristãos, por sua vez, também colocam a liberdade no centro de suas reflexões, embora suas concepções não coincidam e, ainda, difiram-se das duas anteriores. Vê-se a dificuldade do tratamento da questão. A causa da dificuldade está, para Mounier, no fato de se isolar a liberdade da estrutura total da pessoa, exilando-a em alguma aberração (MOUNIER, 1960, p. 105). Decorre daí uma concepção de liberdade, em Mounier, completamente vinculada a sua noção de pessoa.

O ser humano, desde sua emergência até os dias atuais, sempre teve consciência de sua profunda ligação com as determinações naturais; essa ligação, contudo, nem sempre foi expressa de maneira muito clara. $\mathrm{O}$ ser humano primitivo projetava em seres sobrenaturais a origem dos acontecimentos desses determinismos. Apesar de se sentir profundamente escravizado, preso às forças naturais, o ser humano sempre manifestou a possibilidade da liberdade, pois o fato de projetar em seres sobrenaturais a explicação dos determinismos já manifesta certo inconformismo com o determinismo.

A explicitação cada vez mais clara daquilo em que consiste a liberdade impulsionou a criação de instituições que procuram assegurar o pleno exercício das liberdades. Trata-se de uma noção que busca proporcionar liberdade eliminando 
determinações concretas. A mais alta manifestação dessa ideia é a Revolução Francesa, que, de certa forma, sintetiza todas essas aspirações à liberdade, promulgando o direito à liberdade (SEVERINO, 1983, p. 57).

Conscientizado dela - afinal, "se não existe liberdade, que somos nós? Joguetes em pleno universo" (MOUNIER, 1960, p. 105) -, o ser humano procura determiná-la; sente vontade de tocá-la, tal como toca um objeto ou, se não lhe for possível, pelo menos demonstrála em um teorema, a fim de fugir da angústia de não a ter. Todos os seus esforços são em vão. Querer sentir a liberdade em suas mãos é uma ideia ilusória do ser humano, pois ela jamais tolera qualquer determinação.

A liberdade, pois, não pode ser afirmada numa observação objetiva. Para Mounier, "não há no mundo objetivo senão coisas dadas e situações que se cumprem” (MOUNIER, 1960, p. 106). Essa impossibilidade de assentar definitivamente que há liberdade no mundo provoca uma terrível angústia; é-se forçado a crer que o ser humano se encontra entregue ao sabor dos determinismos. Mesmo que a procure, jamais a encontrará em meio às coisas no mundo dos objetos.

Diante dessa situação angustiante, acabou-se formulando uma concepção negativa da liberdade humana, entendendo-a como falhas nos determinismos causais, a fim de se encontrar a existência objetiva da liberdade: "Mas o que posso fazer com lacunas? E é assim que nunca chegamos a descobrir, não diremos na natureza, mas ao seu nível, mais do que duas formas mal-entendidas de liberdade" (MOUNIER, 1960, p. 106). Quer dizer, dos mais variados argumentos que se possam tirar dessas lacunas presentes no determinismo, não se poderão tirar senão duas formas bastante diminuídas de liberdade: uma da indiferença, em que reinaria a indeterminação total, e outra baseada numa eventual falha dos determinismos.

"Fez-se um grande alarde com as novas perspectivas que a física moderna veio abrir, quis-se obrigá-la a 'provar' a liberdade. Era uma ideia totalmente errada de liberdade. A liberdade do homem não é 'resto' duma adição universal." (MOUNIER, 1960, p. 106) Mas o que garante que o indeterminismo físico constatado não seja simples lacuna do conhecimento humano? Antes de ser uma autêntica afirmação da liberdade humana, ele é a plena manifestação do quanto a ciência moderna e/ou o positivismo se encontram assentados sobre frágeis pretensões de perscrutar os mais recônditos rincões do universo, pois a "liberdade não se ganha contra os determinismos naturais, conquista-se por cima deles, mas com eles" (MOUNIER, 1960, p. 107). O que isso quer dizer? A liberdade não é simples coisa, relegada aos pequenos espaços de indeterminismos; contudo, ela não se dá contra os 
determinismos. A liberdade está situada sobre eles. Sendo assim, da mesma forma com que a pessoa transcende a natureza, também a liberdade transcende os determinismos.

A liberdade prolonga-se na natureza. Determinismo e liberdade não são da mesma ordem, mas se interpenetram; não se opõem senão por transcendência. Entre eles há uma relação de apoio e condicionamento. A liberdade deverá apoiar-se sobre suas próprias condições para construir-se, mas, exercendo-se, superará a natureza, sendo para o homem uma característica original e insuperável (SEVERINO, 1983, p. 68).

A ciência, portanto, nada tem a dizer a favor da liberdade; logo, também não tem como renunciá-la, contestá-la. A única coisa que ela mostra é que o universo não é totalizável no plano do determinismo e que ela prepara, lentamente, condições de liberdade. Quer dizer, essas pequenas partículas materiais jamais podem ser tomadas como prova da existência da liberdade no mundo. Esse indeterminismo no máximo revela uma preparação lenta e contínua das condições de liberdade, como bem o mostra a própria história da evolução. Conforme Mounier

No entanto, a liberdade não resulta destes preparativos como fruto da flor. No mistério das forças naturais que os atravessam e misturam, foi reservado para a insubstituível iniciativa da pessoa reconhecer os declives cúmplices da sua liberdade, escolhê-los e neles se comprometer. É a pessoa que se faz livre, depois de ter escolhido ser livre. Em parte nenhuma encontrará a liberdade dada e constituída. Nada no mundo lhe garantirá que ela é livre se não entrar audaciosamente na experiência da liberdade. (MOUNIER, 1960, p. 108)

Não se pode cair, porém, no outro extremo. Uma vez que se afirma que a liberdade não é uma coisa, muitos a reduzem a pura subjetividade, como faz Sartre. Ele defende que o em si (ser objetivo) seria sempre idêntico, imóvel; o para si (ser subjetivo), ao contrário do em si, seria manifestação sempre espontânea, existência livre sempre renovada, autoinvenção, sem limitação alguma, enfim, subjetividade absoluta.

A liberdade tomada dessa forma é um mito, pois não responde a apelo algum. Está certo que a noção de natureza, que inclui permanência e objetividade na ideia de liberdade, encontrase repleta de confusões, mas nem por isso deixa de ter algo de real. Ainda assim, na medida em que desse modo é tomada, a liberdade não responde a nada anterior a ela, pois se isso acontecesse deixaria de ser liberdade; a pessoa não seria mais do que aquilo que ela a si própria se faz: "nela e por ela invento meus motivos, os valores e o mundo comigo, sem apoio de auxílio" (MOUNIER, 1960, p. 109).

Segundo Mounier, afirmar que o ser humano é um ser que existe é afirmar que ele é incessantemente aquilo que se faz. Trata-se de uma "existência que nada 
mais pesaria; existência contra a natureza, que leva à falha ou à inumanidade" (MOUNIER, 1960, p. 85). A noção de natureza sem dúvida é confusa e, por isso, precisa ser repensada. Afirmar que a liberdade não é pura espontaneidade é afirmar que o ser humano não é somente aquilo que se faz, é assumir que "a existência, ao mesmo tempo em que é manifestação espontânea, é também espessura, densidade; ao mesmo tempo em que é criação, é dado" (MOUNIER, 1960, p. 109), como se viu ao falar de imergência e emergência da pessoa.

O ser humano faz parte do mundo, o mundo é anterior ao homem: "Não sou simplesmente o que faço, o mundo não é somente o que quero" (MOUNIER, 1960, p. 109). Caso assim não fosse, não seria possível sequer de falar de humanidade, de história. Somente há humanidade porque é próprio à condição humana ser encarnado, viver situado, o que implica limitações a seu ser, a sua liberdade. Se não se leva em consideração a condição global do ser humano, então facilmente se cai em ideias sem fundamentação, nas quais se explica toda a realidade a partir de uma ideia unilateral. Agora, na medida em que se assume a condição humana, então torna-se visível que

[...] há na própria liberdade um peso múltiplo, o que lhe vem de mim próprio, do meu ser particular que a limita, o que lhe vem do mundo, das necessidades que a constrangem e dos valores que a primem. A sua gravitação é verdadeiramente universal. Quando o esquecemos, subtiliza-se e tende a transformar-se numa sombra, numa ideia de consistência, num sonho impossível; é amorfa e pensam-na absoluta. (MOUNIER, 1960, p. 109)

Ainda, uma liberdade que brota como puro fato é uma natureza cega. A liberdade, nesse sentido, é tomada como uma condenação. Como a liberdade pode ser do homem se ele não a pode recusar? Vê-se o tamanho da confusão. Para Mounier, a liberdade não é uma condenação à qual o homem está sujeito; ao contrário, é um dom. O ser humano pode aceitá-la ou recusála. Ou seja, o ser humano livre é aquele que pode escolher por aceitar ou escolher por errar. Caso a liberdade fosse uma condenação, "as liberdades não mais cooperariam mutuamente, porque a única modalidade de união seria a escravização de uma liberdade por outra" (SEVERINO, 1983, p. 69).

Poder-se-ia perguntar o que aconteceria num mundo onde cada liberdade surgisse de forma isolada. Citando Bakounine, Mounier afirma: "Só serei verdadeiramente livre quando todos os seres humanos que me rodeiam, homens e mulheres, forem igualmente livres [...]. Só me torno livre através da liberdade dos outros" (MOUNIER, 1960, p. 111). Essa visão é completamente excluída, segundo Mounier, de uma concepção que toma a liberdade como incapaz de se unir a outra, pois a liberdade é cooperação: “A 
liberdade da pessoa cria à sua volta liberdade, por uma leveza contagiosa - tal como inversamente a alienação engendra a alienação" (MOUNIER, 1960, p. 111).

Tanto se falou aqui de liberdade, mas quase somente em seu sentido negativo. Se a liberdade não é uma coisa nem manifestação espontânea, então o que é liberdade? Para Mounier, “a liberdade é afirmação da pessoa, vive-se, não se vê” (MOUNIER, 1960, p. 106). Mounier a trata a partir da condição total da pessoa: irredutível a uma coisa natural ou a uma espontaneidade vital, a liberdade, na perspectiva personalista de Mounier, é "fonte viva do ser" (MOUNIER, 1960, p. 111), e como tal atinge todo e qualquer ato humano, transfigurando-o: "Neste sentido e somente neste sentido, o homem é inteiramente livre e sempre livre, interiormente e quando o quiser" (MOUNIER, 1960, p. 111).

Vê-se que a liberdade está em profunda relação com a condição global da pessoa. A liberdade "do homem é a liberdade duma pessoa, desta pessoa, assim constituída e situada em si própria, no mundo e perante os valores" (MOUNIER, 1960, p. 112). O que isso quer dizer? A liberdade se encontra estreitamente condicionada por nossa situação concreta, isto é, da constituição e limitação humanas resulta a concomitante limitação da liberdade humana: ela é condicionada. Nesse sentido, o primeiro passo é tomar consciência de sua situação e aceitá-la. Nem tudo será sempre possível. Aquele a quem é possível se libertar de suas servidões é aquele que toma consciência de que está sendo escravizado. A liberdade, portanto, possui condicionamentos

[...] antes de proclamarmos a liberdade nas constituições, ou de a exaltar em discursos, temos que assegurar comuns condições de liberdade, biológicas, econômicas, sociais, políticas, que permitem às forças médias a participação nos mais elevados apelos da humanidade; temos que nos preocupar com as liberdades, tanto como com a liberdade. Defender "a liberdade" sem outra indicação, sempre que um ato do poder ou um estado de coisas a limitam, é condenarmo-nos a tomar posição ao lado de forças do imobilismo contra as forças dos movimentos. (MOUNIER, 1960, p. 113)

Nossa liberdade é liberdade de pessoas situadas e é também liberdade de pessoas valorizadas. Não se é livre apenas quando se exerce a espontaneidade; torna-se livre se se der a essa espontaneidade o sentido duma libertação, ou seja, duma personalização do mundo e si próprio. A pessoa, portanto, é chamada a se libertar e libertar os outros. Essa libertação não significa a eliminação de todos os condicionamentos; ao contrário, os condicionamentos são apoio para melhor avançar. Por isso, a liberdade não pode ser usada de forma arbitrária, como simples manifestação espontânea, mas deve ser dirigida, conclamada, invocada. 
Mounier defende a necessidade de não se negarem os condicionamentos, pois a liberdade precisa ser conquistada com eles. Tal como é preciso se inserir na história se se quer conhecê-la, é necessário procurar a forma da natureza para daí buscar a libertação. Não se pode, porém, aderir em demasia àquilo que condiciona. A liberdade humana, na verdade, é tomada de forma muito modesta por Mounier, pois é condicionada por todos os lados, mas nem por isso deixa de ser intrépida e audaciosa

Embora modesta, a liberdade do homem dever ser intrépida. Tem-se denunciado o espírito de evasão que descia das tarefas viris. Numa época cada vez mais vergada ao peso do que supõe serem fatalidades, de tal forma roída de preocupações e angústias que está pronta a vender a sua liberdade por um mínimo de segurança, não é menos urgente denunciarmos o espírito de escravidão e suas formas larvadas. (MOUNIER, 1960, p. 116)

O espírito da liberdade, apelo original da existência pessoal, está sempre em luta com o peso da gravidade que atrai os homens para a alienação. O ser humano está em busca constante da libertação, mas jamais a atingirá em definitivo. Através da liberdade são destruídas muitas alienações, isto é, situações que esmagam a pessoa humana, forças impessoais; não se pode negar absolutamente essa característica da autonomia da consciência pessoal diante dos condicionamentos. Por aí se manifesta a transcendência da pessoa sobre a natureza: a retomada pessoal dos valores mostra o domínio do homem sobre a natureza. Mas toda manifestação de transcendência humana traz consigo a alienação: "Sempre que a liberdade tenta seus voos, a natureza prende-a com mil laços" (MOUNIER, 1960, p. 53)

\begin{abstract}
As sujeições que atingem a nossa existência impõem a qualquer situação humana uma alienação mais ou menos difusa: pertence à condição humana aspirar indefinidamente à autonomia, tentar sem cessar atingi-la, e sem cessar falhar na sua procura. Para que fôssemos libertados de qualquer ocasião de alienação, era preciso que a natureza fosse inteiramente inteligível, a comunhão permanente, universal e perfeita, e total a posse de nossos ideais. Mesmo as alienações históricas, as que só duram algum tempo, nos deixam sem tréguas; destruída uma, outra, nova, surge; toda a vitória da liberdade se vira contra ela própria e atrai novos combates; a batalha da liberdade não termina. (MOUNIER, 1960, p. 117)
\end{abstract}

A liberdade humana, portanto, tem essencialmente elevação e queda: consegue despertar e arrancar os espíritos do mais profundo sono, mas, quando comemora, já é lançada a começar novamente a batalha, a fim de lutar contra a alienação da nova situação conquistada: "Assim, de luta em luta, de queda em queda, de vitória em vitória, nesta interminável dialética da fragilidade da pessoa, a liberdade deve ser sempre 
reconquistada" (SEVERINO, 1983, p. 71). Trata-se de uma liberdade que combate. Aqui reina uma atitude de "otimismo trágico"; encontra-se a justa medida num clima de grandeza e de luta.

Essa luta constante pela liberdade contra as alienações é marcada pelo "batismo da escolha". O ser humano tem o poder de escolher: "Optando por isto ou por aquilo, opto de cada vez indiretamente por mim próprio, e na opção me edifico" (MOUNIER, 1960, p. 118). Com as escolhas torna-se possível romper com as fatalidades, criando-se uma nova ordem e uma nova inteligibilidade, mas toda escolha exige do ser humano o arriscar-se na incerteza, sendo somente por ela que o mundo avança e se forma. Se não fosse a liberdade, não haveria a criação de novas ordens para além dos jogos de força.

O centro da liberdade, porém, não é o poder de escolha, como o quis afirmar certa "miopia filosófica". A soberania da liberdade está em seu poder de libertação da pessoa. Nesse sentido, "a liberdade humana não se confunde com liberalismo, mas é também adesão" (RUEDELL, 1985, p. 41), e esta nunca poderá ser imposta do exterior, mas será sempre conquistada, assumida interiormente. Reduzir a liberdade à ideia do poder de opção é fazer com que a liberdade perca seu ímpeto, o que tem de mais precioso. Pois a liberdade, como afirma Mounier em Qu'est-ce que le personnalisme? é

[...] viva, sentida num esforço de libertação mais do que em facilidades herdadas, uma liberdade dramática, conquistada e disputada contra suas próprias obras, uma liberdade devotada em que o sentido do trabalho e da salvação em comum, são os sacrifícios necessários do indivíduo à comunidade e das comunidades presentes aos amanhãs melhores, terão a primazia sobre a reivindicação egocêntrica e imediata. (SEVERINO, 1983, p. 72)

A liberdade em Mounier, portanto, não pode ser somente encarada como ruptura, conquista da autonomia. Liberdade é adesão. Eis porque ela "não é o ser da pessoa, mas o modo como a pessoa é tudo o que é, e é-o mais plenamente do que por necessidade" (MOUNIER, 1960, p. 119). a liberdade pessoal não é de modo algum desligada da existência comunitária das pessoas; A liberdade assim tomada não constitui anarquia, porque é adesão, é compromisso, uma vez que o ser humano "só se liberta libertando".

\section{CONSIDERAÇÕES FINAIS}

Esta investigação tinha por objetivo central verificar a possibilidade e os condicionamentos da liberdade em Emmanuel Mounier. Procurando sempre se 
libertar de visões redutoras do ser humano, Mounier propõe uma nova noção de pessoa, buscando contemplá-la para além de suas manifestações exteriores. O libertar-se de interpretações enviesadas, contudo, sempre exige um grande esforço, pois sabe-se que é mais difícil se libertar de uma crença do que aderir a uma nova. Por isso, toda a exposição da noção de pessoa e, consequentemente, da liberdade em Mounier é acompanhada de uma constante crítica a concepções redutoras do ser humano.

A pessoa, segundo Mounier, possui duas dimensões fundamentais: imergência e emergência. Essa dialética entre imanência e transcendência constitui uma das mais altas expressões do personalismo de Mounier. O espírito humano é limitado, imerso na natureza por uma série de determinismos, mas, para além de sua imergência, o ser humano é capaz de transcendência. $\mathrm{O}$ ser humano pode viver e, de certa forma, tende a viver no nivelamento, no divertimento, na má-fé, na alienação, na inautenticidade, estados de vida que diversos filósofos denominaram como estados de despersonalização; mas também é capaz de abarcar o universo, de ripostar, de transcender, de lançar luz aos mais recônditos rincões do universo.

É nessa noção de pessoa que se dá a liberdade humana. A liberdade, em Mounier, está em profunda relação com a condição global da pessoa, encontra-se estreitamente ligada com os condicionamentos humanos, e por isso é sempre condicionada. Não se trata de uma espontaneidade vital nem de uma lacuna nos condicionamentos, tal como muitas vezes se tem pretendido, mas de um chamado à libertação. A liberdade precisa ser conquistada, conclamada, invocada e, após todo este esforço, precisa ser reconquistada, reconclamada, reinvocada, pois toda libertação traz em seu bojo a alienação.

Esse otimismo trágico, esse clima de elevação e queda que, para muitos, poderia parecer uma negação do ser humano é sua maior grandeza. Da mesma forma como a limitação humana foi expressa por Kant na Crítica da razão pura - "a pomba ligeira agitando o ar com seu livre voo, cuja resistência sente, poderia imaginar que seu voo fosse mais fácil no vácuo”, sem se dar conta de que é a própria resistência do ar que lhe possibilita voar-, assim também muitas vezes não se percebe que é justamente a limitação que faz do ser humano um ser capaz de transcender, de amar, enfim, capaz de liberdade.

Depois de percorrido esse caminho, tem-se a convicção, por um lado, de que os objetivos da investigação foram alcançados e, por outro, do quando ainda falta percorrer. Sabese que o binômio pessoa e comunidade foi fonte inspiradora de toda a temática de Mounier; além do mais, a própria liberdade humana somente pode ser compreendida em sua existência comunitária. A relação desse binômio, contudo, não tem sido 
contemplada em sua amplitude e, portanto, pode vir a ser objeto de uma nova investigação. 


\section{REFERÊNCIAS BIBLIOGRÁFICAS}

MOUNIER, Emmanuel. Introdução aos existencialismos. Trad. João Bénard da Costa. São Paulo: Duas Cidades, 1963. . O personalismo. Trad. João Bénard da Costa. Lisboa: Morais, 1960.

LORENZON, Alino. Atualidade do pensamento filosófico de Emmanuel Mounier. Ijuí: Unijuí, 1996.

RUEDELL, Aloísio. Lições políticas para a América Latina: um estudo do pensamento político de E. Mounier. Canoas: La Salle, 1985.

SEVERINO, Antônio Joaquim. Pessoa e existência: iniciação ao personalismo de Emmanuel Mounier. São Paulo: Cortez, 1983. 